\title{
BISNIS HARAM DAN PENGARUHNYA TERHADAP FISIK DAN PSIKIS MANUSIA
}

\author{
Zumaroh \\ Universitas Islam Negeri Raden Intan Lampung \\ J. Letnan Kolonel H. Endro Suratmin, Sukarame, Kota Bandar Lampung 35131 \\ Email: zumaroh@gmail.com
}

\begin{abstract}
One form of work someone does to produce a variety of products is business. For Muslims, business is always controlled by the law of halal and haram, both in the way of acquisition and utilization. Physically, a person's malicious practices will result in enormous losses, he will experience various diseases that are difficult to cure or even no cure. This affects the depletion of the treasures it has collected in such haram ways. Psychically, the warning and punishment sanctions experienced by malbic businessmen are more dire. In addition to causing various traits and bad traits within himself and his family, he will also experience severe depression and shudder as a manifestation of the aridity of the soul due to his evil behavior in business.
\end{abstract}

Keywords: business haram, physical and psychic human

Abstrak: Salah satu bentuk pekerjaan yang dilakukan seseorang untuk menghasilkan beragam produk adalah bisnis. Bagi umat Islam, bisnis yang dilakukan selalu dikendalikan oleh aturan halal dan haram, baik dalam cara perolehan maupun pemanfaatannya. Secara fisik manusia, praktik malbisnis yang dilakukan seseorang akan berakibat pada kerugian yang sangat besar, ia akan mengalami berbagai penyakit yang sulit disembuhkan atau bahkan tidak ada obatnya. Ini berdampak pada terkurasnya harta yang telah dikumpulkannya dengan cara haram tersebut. Secara psikis, sanksi peringatan dan siksa yang dialami oleh pelaku malbisnis lebih mengerikan. Selain menimbulkan berbagai watak dan sifat buruk dalam diri dan keluarganya, ia juga akan mengalami depresi dan keguncangan batin yang berat sebagai perwujudan dari kegersangan jiwa akibat perilaku jahatnya dalam berbisnis.

Kata kunci: bisnis haram, fisik dan psikis manusia

\section{Pendahuluan}

Dalam hidup dan kehidupan, manusia takkan pernah dapat melepaskan diri dari kebutuhan akan kerja. Keja dilakukan manusia untuk memenuhi berbagai macam kebutuhan. Karenanya, dalam Islam bekerja menjadi hal yang wajib dilaksanakan oleh setiap oarang sesuai dengan kapasitas dan kemampuan dirinya. Tidak dapat disangkal bahwasanya semua bentuk hasil produksi dengan berbagai kualitas dan kuantitasnya merupakan hasil dari sebuah kerja.

Salah satu bentuk pekerjaan yang dilakukan seseorang sehingga menghasilkan beragam produk adalah bisnis. Bagi umat Islam bisnis yang dilakukan selalu dikendalikan oleh aturan halal dan haram, baik dalam cara perolehan maupun pemanfaatan harta. harta yang diperoleh dari bisnis yang halal akan membawa keberkahan yang merupakan cerminan atas pahala yang diterima oleh pelaku bisnis tersebut. Hal tersebut akan terlihat perwujudannya pada kesejahteraan dan ketenteraman seseorang selama menjalankan bisnisnya.

Berbeda halnya dengan bisnis yang dilingkupi oleh keharaman, seperti bisnis-bisnis diskotik, prostitusi, judi, perbankan ribawi dan sebagainya akan membawa kemudharatan yang merupakan manifestasi atas dosa yang diterima oleh pelaku bisnis tersebut. Hal tersebut akan 
memperlihatkan fakta kepada kita bahwa pelaku bisnis haram akan diterpa berbagai penyakit fisik dari yang ringan hingga yang terberat yang dapat berujung pada kematian. Selain itu, secara kejiwaan pelaku bisnis haram tidak akan mendapat ketenteraman dalam menjalankan usaha dan kehidupannya karena selalu dibayangbayangi oleh ketakutan dan kekhawatiran akan mengalami kerugian dan kebankrutan.

Tulisan ini akan mencoba membahas tentang bagaimana bisnis haram dan pengaruhnya terhadap fisik dan psikis (mental) manusia sebagai pelaku bisnis tersebut. Bagaimana besarnya kerugian dan kemudharatan yang ditimbulkan oleh bisnis haram bagi orang yang menjalankannya.

\section{Bekerja Menurut Islam}

Bekerja merupakan salah satu unsur yang terpenting dalam kegiatan ekonomi karena sangat dibutuhkan dalam segala bentuk aktivitas produksi. ${ }^{1}$

Alquran sebagai sumber hukum utama dalam Islam begitu banyak menyebutkan tentang kerja. Frekuensi penyebutan tentang kerja yang begitu banyak menunjukkan betapa pentingnya segala bentuk kerja produktif dan aktivitas yang menghasilkan dalam Islam. Dalam hal produksi, kualitas dan kuantitasnya sangat bergantung pada kerja sehingga Islam menyeru kepada umatnya untuk selalu bekerja dan melarang segala bentuk kemalasan.

Islam menekankan bahwa kerja dan amal merupakan faktor penentu bagi posisi dan status seseorang dalam kehidupan bermasyarakat. Sumber nilai yang riil bagi manusia adalah pekerjaannya. Seseorang akan bernilai guna bila mempunyai pekerjaan. Sebaliknya, seseorang yang tidak bekerja tidak akan dipandang berguna dan mempunyai nilai di masyarakat sekitarnya.

Hal ini sesuai dengan ayat Alquran berikut:

${ }^{1}$ Jaribah bin Ahmad Al-Haritsi, Fikih Ekonomi Umar bin AlKhathab, Terj. Asmuni Solihan Zamakhsyari, (Jakarta: Khalifa, 2006), h. 92.

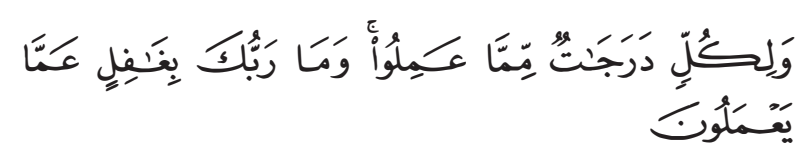

"Dan masing-masing orang memperoleh derajatderajat (seimbang) dengan apa yang dikerjakannya. dan Tuhanmu tidak lengah dari apa yang mereka kerjakan".

Dari ayat di atas dapat dipetik pelajaran bahwa kerja merupakan faktor utama yang menjadi acuan penilaian bagaimana seseorang akan mendapat pahala, penghargaan dan ganjaran di samping iman.

Islam melalui Alquran telah memberikan rambu-rambu terhadap kerja, yaitu: ${ }^{2}$

1. Alquran mendesak umat Islam untuk senantiasa bekerja keras dengan imbalan janji pahala yang berlimpah, pertolongan dan petunjuk bagi mereka yang berjuang (bekerja keras) dan berlaku baik, serta memberikan insentif bagi mereka yang selalu meningkatkan kualitas dan kuantitas kerjanya.

2. Keterampilan dan penguasaan teknologi harus dimiliki seorang pekerja termasuk kemampuan untuk mengoperasikan (memanfaatkan) sarana dan prasarana penunjang kerja untuk memperoleh hasil yang optimal.

3. Islam memberikan pandangan yang positif terhadap seseorang yang bekerja untuk mencukupi kebutuhan hidupnya dan keluarganya, daripada orang yang selalu berpangku tangan dan meminta-minta. Meski Islam sendiri menjamin ada hak orang miskin di dalam harta orang kaya, Islam tetap lebih menghargai orang yang mau berusaha di atas kakinya sendiri dan bekerja dengan tangannya daripada orang yang menggantungkan hidupnya kepada orang lain.

4. Islam mewajibkan dan menganjurkan umatnya untuk bekerja yang halal, baik, produktif dan bermanfaat. Islam memastikan bahwa segala bentuk kerja, baik yang halal maupun yang haram akan dimintai pertanggung jawabannya kelak di akhirat.

\footnotetext{
${ }^{2}$ Mustaq Ahmad, Etika Bisnis Dalam Islam, Terj. Samson Rahman, (Jakarta: Pustaka Al-Kautsar, 2005), h. 9.
} 


\section{Konsep Bisnis Dalam Islam}

\section{Pengertian Bisnis}

Secara umum bisnis dapat diartikan sebagai berikut:

a. Usaha dagang, usaha komersial di dunia perdagangan dan bidang usaha.

b. Pertukaran barang, jasa atau uang yang saling menguntungkan atau memberi manfaat.

c. The buying and selling of goods and services.

d. Suatu organisasi yang menjalankan aktivitas produksi dan penjualan barang dan jasa yang diinginkan konsumen untuk memperoleh profit (keuntungan).

Sedangkan yang dimaksud dengan bisnis islami adalah serangkaian aktivitas bisnis dalam berbagai bentuknya yang tidak dibatasi jumlah (kuantitas) kepemilikan hartanya (barang/jasa) termasuk profitnya, namun dibatasi dalam cara perolehan dan pendayagunaan hartanya (ada aturan halal dan haram). ${ }^{3}$

\section{Landasan Hukum Bisnis}

Islam telah memberi tuntunan tentang bisnis dalam Alquran. Tuntunan tersebut juga diperkuat hadits Nabi saw, di antaranya:

a. Q.S. Ibrahim (32-34)

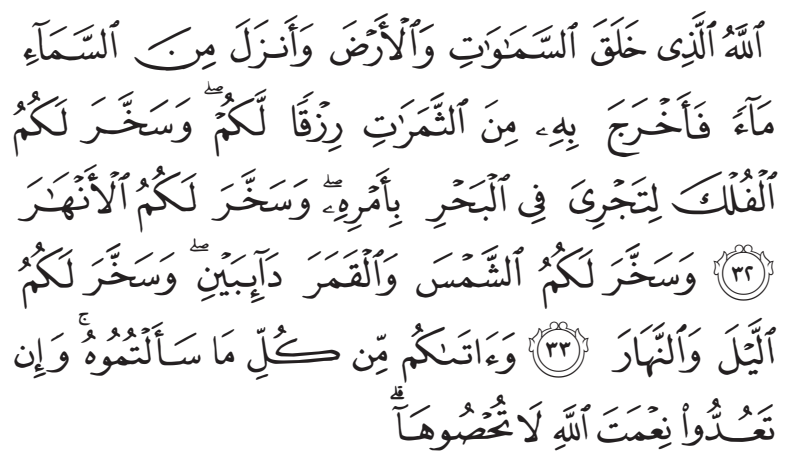

"Allah-lah yang telah menciptakan langit dan bumi dan menurunkan air hujan dari langit, kemudian Dia mengeluarkan dengan air hujan itu berbagai buah-buahan menjadi rezki untukmu; dan Dia telah menundukkan bahtera bagimu supaya bahtera itu, berlayar di lautan dengan kehendak-

${ }^{3}$ M. Ismail Yusanto, M. Karebet Widjajakusuma, Menggagas Bisnis Islami, (Jakarta: Gema Insani Press, 2003), h. 18
Nya, dan Dia telah menundukkan (pula) bagimu sungai-sungai. Dan Dia telah menundukkan (pula) bagimu matahari dan bulan yang terus menerus beredar (dalam orbitnya); dan telah menundukkan bagimu malam dan siang. Dan Dia telah memberikan kepadamu (keperluanmu) dan segala apa yang kamu mohonkan kepadanya. dan jika kamu menghitung nikmat Allah, tidaklah dapat kamu menghinggakannya"

b. Q.S. Al-A'raf (10)

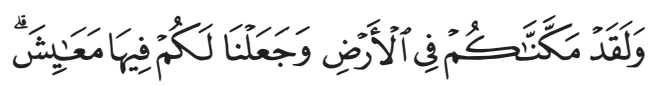

"Sesungguhnya Kami telah menempatkan kamu sekalian di muka bumi dan Kami adakan bagimu di muka bumi (sumber) penghidupan....."

c. Hadis Nabi saw, yang artinya:

"kedua telapak kaki seorang anak Adam di hari kiamat masih belum beranjak sebelum ditanya kepadanya mengenai lima perkara: tentang umurnya, apa yang dilakukannya; tentang masa mudanya, apa yang dilakukannya; tentang hartanya, dari mana ia peroleh dan untuk apa ia belanjakan; dan tentang ilmunya, apa yang dia kerjakan dengan ilmunya itu." (HR. Ahmad)

\section{Segmentasi Bisnis Menurut Islam}

Islam telah membagi bisnis pada umumnya dalam 2 segmen, yakni bisnis yang menguntungkan dan bisnis yang merugikan. Kedua segmen bisnis tersebut dijabarkan sebagai berikut:

\section{a. Bisnis yang menguntungkan}

Dalam pandangan Islam, bisnis yang menguntungkan itu paling tidak mengandung 3 elemen dasar: pertama, melakukan investasi yang terbaik atas harta kekayaan yang dimiliki seseorang dengan ditujukan untuk mencapai ridha Allah. Ridha Allah akan dapat dicapai bila investasi dilakukan di jalan yang baik lagi halal (diinvestasikan di jalan Allah). Untuk hal tersebut Allah telah memberikan garansi bahwa harta yang diinvestasikan di jalan yang benar akan selalu diberkati, ditambah serta dilipat gandakan pahala bagi pemiliknya. 
Kedua, seseorang harus mampu membuat keputusan secara logis, sehat dan bijaksana serta penuh kehati-hatian dalam menginvestasikan dananya. Penginvestasian harta di jalan Allah berarti telah memenuhi ketentuan pengambilan keputusan bisnis tersebut.

Ketiga, seseorang harus mampu berperilaku yang benar dalam berbisnis sesuai dengan tuntunan etika bisnis dalam Islam. Pebisnis tidak boleh melakukan tindakan yang salah dan merugikan orang lain sehingga usahanya akan dijauhkan dari ridha Allah. Kemampuannya menjaga amanah dan janjinya dalam berbisnis sangat diutamakan, karena Allah telah merekomendasikan bahwa pekerjaan yang akan selalu mendatangkan keuntungan adalah pekerjaan yang dilakukan dengan sungguhsungguh dan mengharapkan ampunan-Nya.

\section{b. Bisnis yang merugikan}

Ketidakadaan elemen-elemen yang menjadikan suatu bisnis itu selalu menguntungkan akan menjadikan bisnis itu merugikan. Hal tersebut ditandai dengan kebalikan dari elemen yang dimiliki bisnis yang menguntungkan, yaitu: pertama, investasi atas harta (modal) yang dilakukan untuk jalan yang buruk (tidak di jalan Allah) dalam Islam diibaratkan dengan "membeli dunia dengan akhirat”. Artinya, usaha yang dilakukan tidak dengan cara yang halal tidak akan mendatangkan keuntungan melainkan akan mendatangkan kerugian yang menggiring kepada kebangkrutan. Karena pelaku bisnis yang merugikan ini mementingkan duniawi dengan menghalalkan segala cara serta melupakan kepentingan ukhrawinya. Kesenangan dunia yang pada hakikatnya hanya sementara selalu dikejar dengan mengabaikan bahkan meniadakan kehidupan yang lebih abadi yakni kehidupan akhirat. Pahala akan jauh darinya dan diganti dengan ancaman dosa dan siksa.

Kedua, Alquran menegaskan bahwa keputusan untuk berbisnis di jalan yang tidak diridhai Allah adalah keputusan yang tidak sehat dan akan mengakibatkan kerugian yang sangat besar. Keputusan untuk menjalani bisnis haram merupakan hasil keputusan yang tidak logis dan tidak sehat, hal ini menjauhkan bisnis tersebut dari ridho Allah.

Ketiga, elemen yang menjadikan bisnis itu merugi adalah perilaku jahat. Perilaku yang tidak sesuai dengan ketentuan Allah yang dilakukan pada aktivitas yang dilarang pula konsekuensinya sangat mengerikan di akhirat. Allah akan melakukan perhitungan atas perbuatan mereka karena perbuatan tersebut harus dipertanggung jawabkan. Allah akan menberikan balasan yang setimpal yang tidak pernah diduga saat melakukan kejahatan itu di dunia.

\section{Bisnis Yang Dilarang Menurut Islam}

1. Perilaku Bisnis Yang Dilarang Menurut Islam

Dalam Alquran terdapat 3 terma yang dapat difungsikan sebagai landasan perilaku yang bertentangan dengan nilai-nilai yang dibolehkan Islam khususnya dalam dunia bisnis. Terma tersebut adalah: ${ }^{4}$

\section{a. Al-bathil}

Kata ini berasal dari bathala yang berarti rusak, sia-sia, tidak berguna, bohong. Al-bathil sendiri berarti yang batil, yang salah, yang palsu, yang tidak berharga, yang sia-sia dan syaitan. Terma ini berarti lawan dari kebenaran, yaitu segala sesuatu yang tidak mengandung apa-apa di dalamnya walaupun diteliti; atau yang tidak ada manfaatnya di dunia maupun di akhirat. Penggunaan al-bathil dalam konteks bisnis disebutkan 4 kali dalam Alquran. Pertama, dalam surat $\mathrm{Al}$-Baqarah ayat 188:

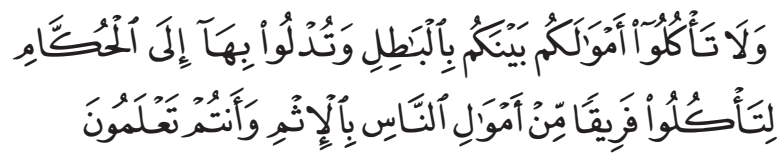

"Dan janganlah sebagian kamu memakan harta sebahagian yang lain di antara kamu dengan jalan yang bathil dan (janganlah) kamu membawa (urusan) harta itu kepada hakim, supaya kamu

4 Lukman Fauroni, Arah dan Strategi Ekonomi Islam, (Yogyakarta: Magistra Insania Press, 2006), h. 76 
dapat memakan sebahagian daripada harta benda orang lain itu dengan (jalan berbuat) dosa. Padahal, kamu mengetahui."

Ayat di atas menegaskan bahwa sifat kebatilan seringkali sengaja digunakan untuk memperoleh harta hingga tahap mengelabui lembaga hukum.

Kedua, dalam surat al-Nisa' ayat 29:

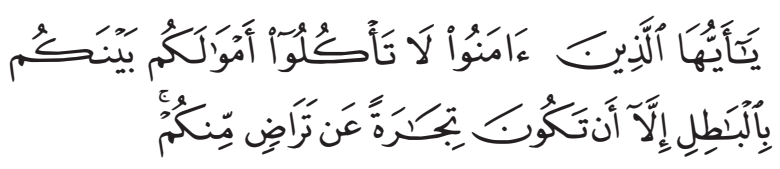

"Hai orang-orang yang beriman, janganlah kamu saling memakan harta sesamamu dengan jalan yang batil, kecuali dengan jalan perniagaan yang Berlaku dengan suka sama-suka di antara kamu..."

Ayat ini menegaskan tentang larangan melakukan bisnis dengan proses kebathilan.

Ketiga, dalam surat al-Nisa' ayat 160-161:

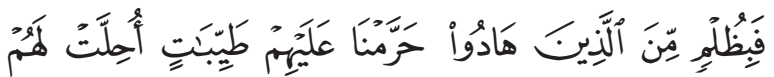

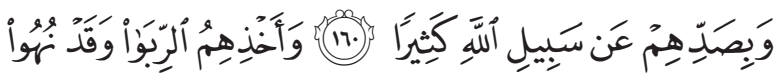

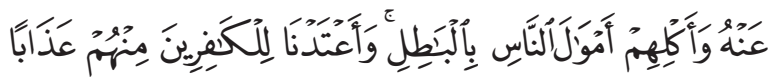

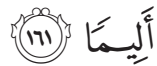

"Maka disebabkan kezaliman orang-orang Yahudi, Kami haramkan atas (memakan makanan) yang baik-baik (yang dahulunya) Dihalalkan bagi mereka, dan karena mereka banyak menghalangi (manusia) dari jalan Allah, dan disebabkan mereka memakan riba, Padahal Sesungguhnya mereka telah dilarang daripadanya, dan karena mereka memakan harta benda orang dengan jalan yang batil. Kami telah menyediakan untuk orangorang yang kafir di antara mereka itu siksa yang pedih."

Ayat di atas mengambil konteks kezaliman yang dilakukan kaum Yahudi yang selalu senang melakukan riba dan memakan harta orang lain dengan bathil.

Keempat, dalam surat al-Taubah ayat 34:

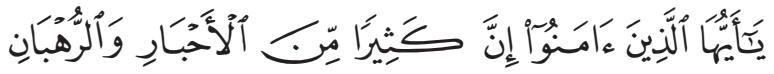

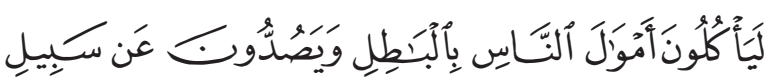

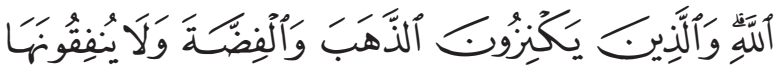

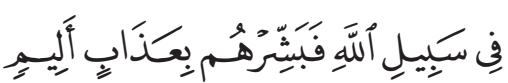

"Hai orang-orang yang beriman, Sesungguhnya sebahagian besar dari orang-orang alim Yahudi dan rahib-rahib Nasrani benar-benar memakan harta orang dengan jalan batil dan mereka menghalang-halangi (manusia) dari jalan Allah. dan orang-orang yang menyimpan emas dan perak dan tidak menafkahkannya pada jalan Allah, Maka beritahukanlah kepada mereka, (bahwa mereka akan mendapat) siksa yang pedib"

Ayat ini menyebutkan bahwa kebathilan dalam bisnis telah dilakukan dalam berbagai bentuk, baik dengan menghalang-halangi dari jalan Allah, menimbun harta atau tidak mengeluarkan infak.

\section{b. Al-fasad}

Terma ini kebanyakan mempunyai arti kebinasaan, kerusakan, membuat kerusakan (yang rugi), kekacauan di muka bumi, menimbulkan kerusakan atau mengadakan kerusakan di muka bumi. Termasuk di dalamnya mengurangi takaran dan timbangan sebagaimana disebutkan dalam surat Huud ayat 85:

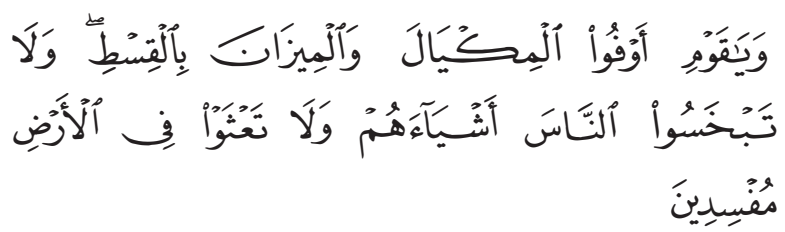

"Dan Syu'aib berkata: "Hai kaumku, cukupkanlah takaran dan timbangan dengan adil, dan janganlah kamu merugikan manusia terhadap hak-hak mereka dan janganlah kamu membuat kejahatan di muka bumi dengan membuat kerusakan."

Perintah menyempurnakan takaran dan timbangan tersebut disandingkan dengan larangan mengadakan kerusakan di muka bumi sebagaimana disebutkan dalam surat al-A'raf ayat 85 :

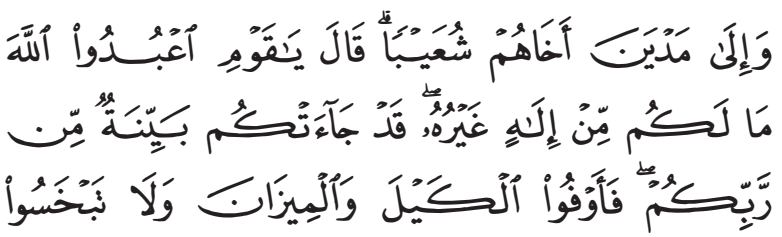




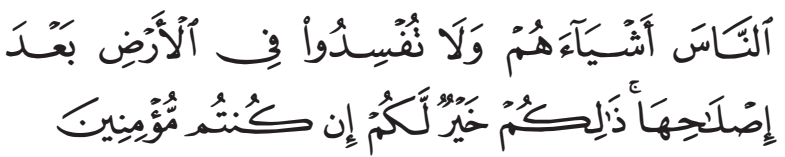

"Dan (Kami telah mengutus) kepada penduduk Mad-yan saudara mereka, Syu'aib. ia berkata: "Hai kaumku, sembahlah Allah, sekali-kali tidak ada Tuhan bagimu selain-Nya. Sesungguhnya telah datang kepadamu bukti yang nyata dari Tuhanmu. Maka sempurnakanlah takaran dan timbangan dan janganlah kamu kurangkan bagi manusia barangbarang takaran dan timbangannya, dan janganlah kamu membuat kerusakan di muka bumi sesudah Tuhan memperbaikinya. yang demikian itu lebih baik bagimu jika betul-betul kamu orang-orang yang beriman".

Disebutkan pula dalam surat al-Maidah ayat 32 tentang bagaimana besar dan luasnya akibat yang ditimbulkan oleh kezaliman:

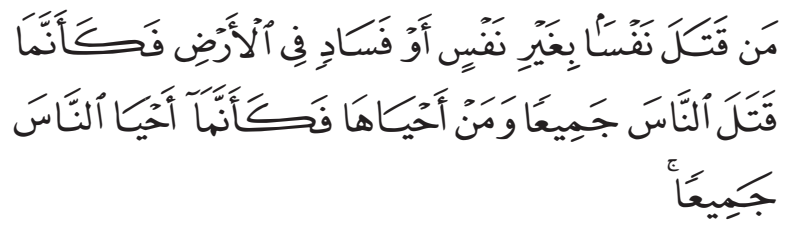

"...Siapa yang membunuh seorang manusia, bukan karena orang itu (membunuh) orang lain, atau bukan karena membuat kerusakan dimuka bumi, Maka seakan-akan Dia telah membunuh manusia seluruhnya. dan Barangsiapa yang memelihara kehidupan seorang manusia, Maka seolah-olah Dia telah memelihara kehidupan manusia semuanya..."

\section{c. Al-zhalim}

Al-zhulm mempunyai makna meletakkan sesuatu tidak pada tempatnya, ketidakadilan, penganiayaan, penindasan, tindakan sewenangwenang dan kegelapan. Al-zhalim berarti tidak adanya cahaya, gambaran dari kebodohan, kesyirikan, kefasikan. Dalam surat Al-Baqarah (2) ayat 279 dinyatakan:

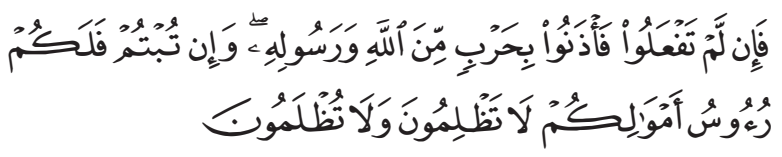

"Maka jika kamu tidak mengerjakan (meninggalkan riba), maka ketahuilah, bahwa Allah dan
Rasul-Nya akan memerangimu. Dan jika kamu bertaubat (dari pengambilan riba), maka bagimu pokok hartamu; kamu tidak menganiaya dan tidak (pula) dianiaya."

Allah mengatakan dalam ayat tersebut bahwa kita seharusnya tidak menganiaya dan tidak pula dianiaya pihak lain.

Dalam surat Ibrahim (34) sebagaimana telah dikemukakan di muka bahwa manusia telah sering berbuat zhalim terhadap sesama dan mengingkari nikmat yang diberikan Allah.

Dari pemahaman tentang terma al-bathil, alfasad, dan al-zhalim jika dikaitkan dengan hakikat bisnis, dapat ditarik suatu benang merah bahwa salah satu landasan malbisnis (bisnis yang dilarang) adalah setiap praktik bisnis yang mengandung kebathilan, kerusakan dan kezhaliman baik sedikit maupun banyak, tersembunyi ataupun terangterangan, dapat menimbulkan kerugian secara material maupun immateri baik bagi si pelaku, pihak lain maupun masyarakat luas. Ketiga terma tersebut jika terdapat salah satunya di dalam praktik bisnis akan menimbulkan akibat moral maupun akibat hukum bagi yang mengikutinya, baik menurut hukum agama maupun hukum positif. Hal tersebut juga dapat menimbulkan ketidak seimbangan dan ketidak adilan.

Terwujudnya kegiatan malbisnis (bisnis terlarang/haram) tidak mensyaratkan adanya 3 landasan terma tersebut sekaligus, melainkan keberadaan 1 terma saja dalam suatu aktivitas bisnis, maka secara otomatis aktivitas serta entitas bisnis tersebut masuk ke dalam kategori praktik malbisnis.

Manifestasi dari ketiga terma tersebut dalam perilaku bisnis, di antaranya berwujud riba, mengurangi takaran atau timbangan, penipuan (tadlis), gharar, skandal, korupsi dan kolusi, monopoli serta penimbunan.

\section{Bisnis Yang Tidak Sah}

Bisnis yang tidak sah (haram/ dilarang) berdasarkan landasan terma di atas dapat dijabarkan sebagai berikut: 


\section{a. Riba}

Riba menurut bahasa berarti ziyadah (tambahan). Secara linguistik artinya tumbuh dan membesar. Menurut istilah artinya pengambilan tambahan dari harta pokok atau modal secara bathil (bertentangan dengan prinsip muamalah dalam Islam), baik dalam transaksi jual beli maupun pinjam meminjam. ${ }^{5}$

Larangan terhadap praktek riba ini tidak diturunkan sekaligus, melainkan secara bertahap yaitu: tahap pertama, menolak anggapan bahwa pinjaman riba yang pada zahirnya seolah-olah menolong mereka yang memerlukan sebagai suatu perbuatan mendekati atau taqarrub kepada Allah Swt. (Al-Rum: 39).

Tahap kedua, riba digambarkan sebagai suatu yang buruk. Allah mengancam akan memberikan balasan yang keras terhadap orang Yahudi yang memakan riba. (An-Nisa': 160-161).

Tahap ketiga, riba diharamkan dengan dikaitkan kepada suatu tambahan yang berlipat ganda. (Ali 'Imran: 130).

Tahap keempat, Allah dengan jelas dan tegas mengharamkan apapun jenis tambahan yang diambil dari pinjaman. (Al-Baqarah: 278-279).

\section{b. Penipuan}

Alquran menolak praktik penipuan dalam bentuk apapun. Penipuan digambarkan oleh Alquran sebagai karakter utama kemunafikan, yang diancam dengan siksa yang pedih bagi pelakunya. sebagaimana firman Allah dalam surat al-Nisa' (145):

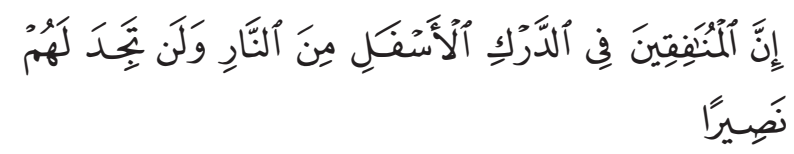

"Sesungguhnya orang-orang munafik itu (ditempatkan) pada tingkatan yang paling bawah dari neraka. dan kamu sekali-kali tidak akan mendapat seorang penolongpun bagi mereka."

Beberapa praktik yang termasuk dalam

${ }^{5}$ M. Syafi'i Antonio, Bank Syariah Dari teori Ke Praktek, (Jakarta: Gema Insani Press, 2001), h. 37 kategori penipuan adalah tathfif (curang dalam timbangan), tidak jujur, bohong dan ingkar janji, menyembunyikan barang yang buruk di dalam tumpukan barang yang bagus, pertukaran yang dilakukan semata-mata atas dasar perkiraan (spekulasi) kuantitas dari suatu komoditas yang diperjual belikan, jual beli barang yang belum jelas ada barangnya, mencegat barang dagangan sebelum sampai ke pasar dan membelinya dengan harga lebih rendah dari harga pasar, mejual barang dengan dua harga, dan semua bentuk bisnis yang mengandung unsur penipuan. ${ }^{6}$

\section{c. Bisnis lain yang tidak sah}

Bentuk bisnis lain yang tidak sah (haram) adalah segala bentuk praktik yang memakan kekayaan orang lain dengan cara-cara yang bathil, meliputi: pertama, tidak menghargai prestasi. Ini berkaitan dengan penempatan seseorang atas suatu jabatan (pekerjaan) yang tidak ia miliki kompetensinya karena merupakan ketidakjujuran sekaligus ketidakadilan. Kedua, partnership (kerja sama kemitraan) yang tidak valid karena dilakukan secara unprosedural semisal hanya menempelkan nama tanpa memberikan kontribusi kerja pada bisnis yang dilakukan. Bentuk partnership seperti ini tidak berhak mengambil keuntungan karena tidak bermoral dan tidak sah secara hukum. Ketiga, pelanggaran dalam pembayaran gaji dan utang tanpa alasan yang jelas dan rasional merupakan tindakan yang bathil dan zhalim karena menggantung nasib orang lain serta melanggar hak-hak pekerja. Keempat, penimbunan barang dan melakukan hal yang menimbulkan melambungnya harga sehingga mengakibatkan kerugian dan kesulitan masyarakat secara luas, biasanya dilakukan untuk melambungkan harga karena terjadi kelangkaan barang sehingga menimbulkan krisis. Kelima, penentuan harga yang fix oleh pemerintah serta proteksionisme karena akan mencegah terjadinya mekanisme pasar, menimbulkan upaya bertransaksi black market dan berdampak pada ketidakadilan. Keenam, hima dan monopoli yang mencegah perdagangan bebas dan menghambat

\footnotetext{
${ }^{6}$ Mustaq Ahmad, Etika Bisnis..., h. 136
} 
manusia memperolah harga secara adil, ketujuh, tindakan yang menimbulkan kerusakan dan praktik pemaksaan yang mengakibatkan kerugian serta merupakan bentuk penindasan terhadap terhadap orang lain. Kedelapan, mengkonsumsi hak orang lain dengan cara yang bathil sebagaimana telah dipaparkan dalam pembahasan di atas yang merupakan perbuatan tidak adil dan diharamkan dalam Islam. ${ }^{7}$

\section{Pengaruh Bisnis Haram Terhadap Fisik Dan Psikis Manusia}

Bisnis yang tidak dilakukan di jalan Allah (bisnis haram) sudah dipastikan dalam Alquran maupun hadits akan membawa dampak buruk baik bagi fisik maupun psikis (mental) manusia yang menjadi pelaku malbisnis (bisnis haram) tersebut. Seberapa besar dampaknya dapat dilihat dalam penjabaran berikut:

Seseorang biasanya berusaha memenuhi kebutuhannya (mencari rezeki) dengan bekerja atau berbisnis. Namun, bisnis yang dilakukan dengan cara korupsi, penipuan, manipulasi, pemaksaan kepada seseorang, dan cara-cara lain yang tidak benar, akan membuahkan rezeki yang dimakan oleh keluarganya tidak halal. Rezeki yang diperoleh dengan cara tidak halal tentu akan membawa pengaruh bagi mereka. Darah yang mengalir dalam tubuh anak dan keluarganya adalah saripati makanan yang diperoleh secara tidak halal. Akhirnya, anak akan menjadi anak yang tidak diridhoi Allah dan akan cenderung menjadi anak yang nakal. ${ }^{8}$

Selain berpengaruh pada perilaku orang tersebut dan keluarganya, orang yang mencari harta dengan memakan harta orang lain, maka keluarganya dalam kehidupannya tidak akan mendapat keberkahan. Banyak orang yang dengan sangat mudah dan cepat memperoleh hartanya, akan tetapi perginya harta tersebut tidak kalah cepatnya. Uang dan hartanya akan mengalir ibarat derasnya air bah yang tanpa ada

\footnotetext{
${ }^{7}$ Mustaq Ahmad, Etika Bisnis..., h. 142

8 A. Khoerussalim, To be The Moslem Entrepreneur, (Jakarta:Pustaka Al-Kautsar, 2005), h: 168
}

kesempatan sedikitpun untuk menikmatinya dengan tenang dan nyaman, sehingga harta itu tidak mempunyai nilai manfaat yang hakiki. Banyak orang kaya raya yang segera terkuras habis hartanya untuk berobat dari sakit yang berat dan tidak ada obatnya. Sakit yang diderita tersebut merupakan hukuman yang diberikan Allah sebagai imbalan atas perbuatannya ketika mencari rezeki secara tidak halal. Allah menghabiskan hartanya dengan sakitnya.?

Alquran dalam memerangi ekonomi ribawi tidak serta merta memberikan hukuman fisik maupun denda. Hukuman ini lebih bersifat penekanan psikis ketika menyamakan pemakan riba dengan orang yang kesurupan syaitan, sebagaimana dikemukakan dalam surat Al-Baqarah ayat 275 bahwa orang yang bermuamalah dengan menerapkan asas ribawi dan menghisap keringat-darah orang lain, kelak di akhirat tidak dapat berjalan tegak kecuali bagaikan anjing gila yang tidak bisa berjalan tegak karena selalu berjalan gontai, tehuyung-huyung dan sempoyongan. Betapa buruknya gambaran bagi para pemakan riba dan rentenir ini tidak terbatas pada kehidupan akhirat yang masih lama, di dunia mereka diidentikkan dengan lintah darat yang suka menghisap darah hewan dan manusia. Begitu hinanya penggambaran ini akan memberikan tekanan psikis bagi para pelakunya. Diakui ataupun tidak, mereka tidak akan mendapatkan ketenteraman dan kebahagiaan dalam menjalankan kehidupan dan usahanya. Dihantui kecemasan, ketakutan dan rasa bersalah, itulah yang akan selalu mereka alami meskipun jika di hadapan orang lain mereka bersikap seperti manusia super yang kebal terhadap berbagai ancaman hukum baik hukum Tuhan maupun hukum positif. Namun di dalam diri dan batinnya, mereka adalah manusia yang sangat rapuh. ${ }^{10}$

Maulana al-Maududi sebagaimana dikutip

${ }^{9}$ A. Khoerussalim, To be The Moslem..., h. 168

${ }^{10}$ M. Amin Suma, Mengurai Akar Menggali Serat Ekonomi dan Keuangan Syariah, Kholam (Jakarta: Publishing, 2008), h. 208. Lihat juga: Muhammad, Aspek Hukum dalam Muamalat, (Yogyakarta: Graha Ilmu, 2007), h. 89. 
Mustaq Ahmad dalam 'Etika Bisnis Dalam Islam"l mengemukakan bahwa kejahatan riba akan menimbulkan berbagai dampak negatif bagi manusia yang melakukannya, yaitu:

1. meningkatkan rasa tamak, menimbulkan rasa kikir yang berlebihan, mementingkan diri sendiri, keras hati, tirani dan memuja uang.

2. menimbulkan kebencian dan permusuhan dan bukannya simpati dan kooperasi.

3. mendorong terjadinya penimbunan akumulasi kekayaan dan menghambat adanya investasi langsung dalam perdagangan. Jika diinvestasikan pun akan dilakukan demi kepentingan pribadi tanpa memperhatikan kepentingan masyarakat.

4. mencegah terjadinya sirkulasi kekayaan karena kekayaan itu hanya akan berada di tangan-tangan para pemilik modal.

Bisnis yang tidak lagi berpijak pada satu acuan normatif yang menetapkan apa seharusnya yang baik (sebutlah bisnis haram) akan menyesatkan menjadi bumerang bagi manusia pelakunya sendiri karena berakibat pada depresi dan guncangan batin yang hebat dalam dirinya. Ketika titik kulminasi depresi dan guncangan batin akibat tidak dapat memuaskan dahaga batin tersebut akan hidup bergelimang harta terjadi maka kegersangan jiwalah yang akan dialaminya. Jiwa yang gersang menggiring pada perilaku yang tidak konsisten lagi dalam menjalani aktivitas bisnisnya. Ia akan kehilangan tumpuan dan arah sehingga bisnisnya pun mengalami kerugian yang amat besar. Maka akan semakin terguncanglah batin mereka.

Bisnis yang dilakukan dengan cara gharar (ketidakpastian/ spekulasi) dan penipuan serta kecurangan di dalamnya ataupun berbagai bentuk bisnis yang tidak sah (haram) lainnya, akan mengakibatkan kesalahpahaman di antara dua pihak yang akan memunculkan percekcokan di antara sesama pelakunya. Di samping itu, juga dapat menimbulkan permusuhan di antara

\footnotetext{
${ }^{11}$ Mustaq Ahmad, Mustaq Ahmad, Etika Bisnis..., h. 133
}

mereka karena salah satu pihak ada yang merasa dirugikan ataupun dikhianati oleh pihak lain. ${ }^{12}$

\section{Penutup}

Berdasarkan paparan di atas, dapat disimpulkan bahwa segala bentuk bisnis yang haram akan membawa pengaruh yang buruk terhadap diri manusia yang menjadi pelakunya. Berbagai kecaman dan ancaman yang ditegaskan Allah Swt dalam Alquran maupun yang disabdakan oleh Rasulullah saw sangat jelas dan tidak ada satupun pernyataan yang mentolerir paktik malbisnis tersebut.

Secara fisik manusia, praktik malbisnis akan berakibat pada kerugian yang teramat besar, berbagai penyakit yang sukar atau bahkan tidak ada obatnya akan ditimpakan kepadanya yang berdampak pada terkurasnya harta yang telah dikumpulkannya dengan cara haram tersebut. Sehingga harta yang dimilikinya akan habis dengan mudah dan mengalir cepat seperti banjir sungai.

Secara psikis, sanksi peringatan dan siksa yang dialami oleh pelaku malbisnis lebih mengerikan. Selain menimbulkan berbagai watak dan sifat buruk dalam dirinya dan keluarganya, ia juga akan mengalami depresi dan keguncangan batin yang berat sebagai perwujudan dari kegersangan jiwa akibat perilaku jahat dan haramnya dalam berbisnis.

Yang terpenting adalah bahwa praktik malbisnis yang dilakukan akan membawa akibat pada sanksi sosial dan individual baginya dan keluarganya. Di masyarakat, meski tampaknya dihormati sebagai orang terpandang, namun sebenarnya ia dikucilkan dan dianggap sebelah mata keberadaannya. Secara pribadi, ketenangan, ketenteraman, dan kebahagiaan hakiki akan jauh darinya dan keluarganya. Yang ada adalah perasaan yang selalu dikejar kecemasan dan ketakutan akan kehilangan hartanya serta bayangan siksa yang akan diterima di akhirat.

${ }^{12}$ Abdullah Al-Mushlih, Shalah Ash-Shawi, Fikih Ekonomi Keuangan Islam, Terj. Abu Umar Basyir, (Jakarta: Darul Haq, 2004), h. 386 
Tampak jelaslah, betapa tidak setimpalnya apa yang ia peroleh di dunia berupa kenikmatan semu yang sesaat dengan ancaman siksa di akhirat yang kekal.

\section{Pustaka Acuan}

Ahmad, Mustaq, Etika Bisnis Dalam Islam, Terj. Samson Rahman, Jakarta: Pustaka AlKautsar, 2005.

Antonio, M. Syafi'i, Bank Syariah Dari teori Ke Praktek, Jakarta: Gema Insani Press, 2001

Depag RI, Alquran dan Terjemahnya, Semarang: Toha Putra, 1989.

Fauroni, Lukman, Arah dan Strategi Ekonomi Islam, Yogyakarta: ,Magistra Insania Press, 2006.
Haritsi, Jaribah bin Ahmad al-, Fikih Ekonomi Umar bin Al-Khathab, Terj. Asmuni Solihan Zamakhsyari, Jakarta: Khalifa, 2006.

Khoerussalim, A., To be The Moslem Entrepreneur, Jakarta: Pustaka Al-Kautsar, 2005.

Muhammad, Aspek Hukum dalam Muamalat, Graha Ilmu, Yogyakarta, 2007.

Mushlih, Abdullah al-, Shalah Ash-Shawi, Fikih Ekonomi Keuangan Islam, Terj. Abu Umar Basyir, Jakarta: Darul Haq, 2000.

Suma, M. Amin, Mengurai Akar Menggali Serat Ekonomi dan Keuangan Syariah, Jakarta: ,Kholam Publishing, 2008.

Yusanto, M. Ismail, M. Karebet Widjajakusuma, Menggagas Bisnis Islami, Jakarta: Gema Insani Press, 2003. 